\title{
A REVIEW ON MEASURING ENTREPRENEURS' SOCIAL BEHAVIOUR VIA SPATIAL ANALYSIS TECHNIQUES
}

\author{
Nawawi, N. M*, Ujang, U., Azri, S., and Choon, T.L. \\ Geoinformation, Faculty of Built Environment and Surveying, Universiti Teknologi Malaysia (UTM), Johor, Malaysia - \\ noorain48@gmail.com, \{mduznir, suhaibah, tlchoon\}@utm.my
}

KEY WORDS: Human Behaviour, Entrepreneur Behaviour, GIS, Spatial Measurement, Spatial Analysis

\begin{abstract}
:
This article reviews the subject of entrepreneur with a focus on the components of the entrepreneurial personality traits that are reflected in entrepreneur behaviour. Human behaviour receives a warm welcome in social psychology for examination and measurement of individual social behaviour. There are a number of tools to measure human behaviour in social science such as Likert scale, Indices, Social Network Analysis, E-scan and lastly most popular Big Five Factor Model. In entrepreneurship, entrepreneur's personality can be reflected in their action, activity, and behaviour in certain space such as traveling to find raw resources in certain distance or their decision on size of the shop. Using in-depth observation and examination of this behaviour, there are several spatial elements that could lead to the possibility in implementing spatial measurement in entrepreneur behaviour. However, there is a scarcity of research and implementation of the spatial measurement on entrepreneur behaviour, even though it is already acknowledged that space influences human behaviour and vice versa human behaviour has an impact on space. Thus, this article aims to highlight the possibility of implementing spatial measurement in entrepreneur behaviour and current exploration of spatial measurement for human behaviours.
\end{abstract}

\section{INTRODUCTION}

\subsection{Entrepreneurship}

Entrepreneurship is a very common phenomenon in our real life and has become the backbone of most national economies (Khalique, 2011). People nowadays have a positive view toward entrepreneurship. Typically, most researchers will choose the definition that best fits their research and viewpoint. There are various definitions of entrepreneur and entrepreneurship. According to Shane \& Venkataraman (2000), entrepreneurship is a discovery, evaluation, and exploitation of opportunities, in other words, creation of new products, services, or production processes. It includes a new strategy, organization, and new markets (area) and new ideas or enhanced entrepreneurship ideas. Usually a new entrepreneurship originally begins in small-sized at one location (Sorenson, 2005). With continuous effort, some of entrepreneurships can develop into a company that manages to build enterprise networks across one area or several areas that deserve to be called an empire, for example Kentucky Fried Chicken (KFC).

Entrepreneurs are individuals or group who have started or own a business founded upon their own risk at certain time and certain location. Entrepreneurship usually starts with an individual who is a risk taker who generates a new idea and turns it into products or services to generate income (Khan, 2014). Entrepreneurs produce their own products or services based on every open opportunity that others may fail to recognize. These entrepreneurial activities are carried out with the initiative, creativity, and entrepreneurial efforts including preparing or searching for raw materials in certain places to produce their products (Asamani, \& Mensa, 2013). Most entrepreneurs are willing to bear calculated high risk in order to obtain self-satisfaction, social recognition and financial gain (Buang, 2002; Naude, 2010; Wong et al., 2005).
In recent decades, entrepreneurship has received great attention from around the world as a driver for economic growth, initiator for technology growth and innovation for social-economic development. Entrepreneurships also by nature become an option for job seekers to support employment by creating opportunities for other job seekers (Baumol, 1996). This is because an entrepreneur who starts up in backward or less developed area can be an initiator for that area's development (Korent et al., 2015). This will lead to improvement of infrastructure such a new building, water supply, electricity, better roads and other related facility to support the growth of business in that area. With this improvement, one sector that might be affected positively is entrepreneur's standard way of living, which will at the same time change the standard of living in a community in that area and nearby area. On the other hand, entrepreneurs are an agent in adopting innovation and technology to help in improvements of their staff and consumers' quality of life.

The use of new machine technology for production of products in bulk can lead to reduction of time and size of human workforce needed, while community can utilize high quality product at lower price. Lastly, entrepreneur play an important role in fulfilling the requirement and demand of community; without entrepreneur, the country will solely depend on imported products, which will lead to decrease of Gross Domestic Product (GDP) per capita (Doran et al., 2018; SME Corp 2010). Due to this reason, entrepreneurship has become dynamic and has gained recognition in academic studies (Hachana et al., 2018). Usually, external factors and internal factors that affect the success of entrepreneur is an essential sub section in entrepreneurship topic. Generally, common external factors affecting entrepreneurship are financial factor, environmental factor, government support, training and skills, business size, location, and number of employees while internal factors include personality trait and behaviour of the entrepreneur (Mahmood, 2009). 
Considering only the financial factor in decision making for granting loans could raise questions as facts show that $50 \%$ of entrepreneurships are facing crisis and will fail within five years. Based on a literature review on granting loans to entrepreneurs, Kerr et al., (2017) conclude that measuring personality traits of entrepreneur in objective ways is needed. This situation leads entrepreneur to become one of the major subjects of entrepreneurship research. (Frese \& Gielnik, 2014) reported that, during the period 1980-2005, research on entrepreneurship focused more on economic and strategy theories (Kirchhoff, 1991). In this recent decade, research has continued to explore and investigate entrepreneur personality trait and behaviour in helping them to continue and stay with their entrepreneurship (Brandstätter, 2011). Typically, personality trait or behaviour of entrepreneurs are abundant in view and research on psychology and social perspective as the prevalence of current research, but only a few researches have been conducted with a focus on spatial aspect.

\section{ENTREPRENEUR BEHAVIOUR}

\subsection{Entrepreneur Behaviour Reflected from Entrepreneur Personality Traits}

Entrepreneur behaviour has become the focus of attention and the main focus of research. Entrepreneur personality trait and behaviours have been stated as one of the contributors in entrepreneurship success (Guerrero et al., 2008). Almost every entrepreneur should have the same personality traits that could be reflected in their behaviour, which leads to the following positive features in imitating, discovery, and exploitation of entrepreneurship (Chell et al., 1991). Personality traits reflect behaviour patterns (Aitken, 1991), or in other words, an individual's characteristics are reflected in the patterns of thinking, feeling, and behaving (APA, 2017). Meanwhile, human behaviour is action, cognitions and emotions, and belief Entrepreneur's behaviour is a part of entrepreneur activities, emotion, feeling, thoughts, and action in attempt to explore and exploit a new idea or enhance the idea of entrepreneurship (Kirkley, 2016).

\begin{tabular}{|l|l|}
\hline Ability in identify role & Confident \\
\hline Competence & High commitment/motivation \\
\hline Motivation & Persistence / Perseverance \\
\hline Able to make change & Efforts/ Initiative \\
\hline Problem solver & Opportunity orientation \\
\hline Need for achievement & Responsible/ honesty \\
\hline Innovative \& creative & Self-efficacy \\
\hline Risk taker & Locus control \\
\hline Able to change & Endurance \\
\hline Know the role & Determination \\
\hline \multicolumn{2}{|l|}{ Table 1 Personality traits often contributed to Entrepreneurs' } \\
\multicolumn{2}{|c|}{ success }
\end{tabular}

Although much research has focused on explaining and reviewing entrepreneur personality trait and behaviour, the findings still vary depending on type of entrepreneurship, entrepreneurship phase, environment, social norm, area, or location of entrepreneurship (Main Street, urban area). In addition, entrepreneur's behaviours are constantly changing which leads to the complexity of entrepreneur behaviour research.

There is rich literature that has already emphasised that various types of entrepreneur behaviours based on personality trait could lead to success of entrepreneur (Table 1). Kirby (1992) pointed out four personality traits and behaviours of entrepreneur, which includes the ability in identifying role, competence, motivation, and ability to impose change. Zaidatol (2007) stated that entrepreneurs must be creative, innovative, initiative, confident, problem solver, endurance, and responsible are behaviours needed in posed entrepreneurship. Chell (2008) suggested that an entrepreneur should have an internal locus of control, moderate risk-taking propensity, and high need for achievement, while Markman \& Baron (2003) stated entrepreneur should have self-efficacy, opportunity recognition, and perseverance. Few personality traits are selected as most general research points out the same personality traits and these personality traits obviously had spatial elements which could be measured.

The common behaviours selected are locus of control, risk taking, creative and innovative, responsible, honest, endurance, perseverance, confidence, determination, commitment, opportunity orientation and effort (Buang, 2002, Yusof, 2003). Usually these personality traits can be reflected by the action or behaviours of entrepreneur in order to start, survive, and establish their entrepreneurship. For example, commonly, entrepreneur who has great responsibility personality traits will try his/her best to fulfil the order received from costumer in whatever condition, no matter the size of order or distance from the shop. Opportunities orientation entrepreneur will be able to recognize any potential raw material surrounding the shop and turn it into product or service to gain profit or to fulfil demand from nearby community.

\subsection{Existing Measurement for "Unmeasured" Entrepreneur Behaviour}

As entrepreneur behaviour has been emphasized as great contributor to entrepreneurial success, many attempts have been made to measure the behaviour in order to identify potential of entrepreneur. Generally, behaviour is difficult to measure, but previous researchers have worked hard to find ways to measure something that is intangible and cannot be measured (uncountable). However, measurements of behaviour are constrained by access to individual activities, communities, country, and lack of spatial factor consideration and diversity of culture. All of these challenges may be overcome if resources are abundant and valuators have the necessary skills.

\subsection{Non-Spatial Measurement for Human Behaviour:}

The tool described below is appropriate to be used in social science or non-spatial measurement and assessment. This approach is a combination of qualitative and quantitative tools.

2.3.1 Likert scales: Likert scales are one of the most widely used tools in social science to quantify data during interview, survey and focus groups (Joshi et al., 2015). This tool gives more objective perspective to researcher by providing a scale ranged from 3 to 7 or more options (Table 2) for respondents, compared to simple questions requiring only a yes and no response (Jamieson, 2004). Likert tool is suitable for both micro and macro scales and is one of the most reliable ways to measure opinions, perceptions, and behaviours (Podsakoff et al., 2003).

Basically, answers given represent respondent's opinion with the pre-determined scale. Likert scale is great for digging in depth about one particular topic to discover respondent's opinion in greater detail. Likert scale can be used to track minor 
changes in particular group of chosen respondents. However, the disadvantage and limitation of Likert scale is that it cannot explain the reason for an opinion. However, this limitation and disadvantage can be overcome by adding open ended questions so that the respondent can explain the logic behind their answer. The data obtained from Likert scales can be quantified and analysed by statistical analysis. Likert scale is usually not viewed as interval scales but as ordinal scales. In other words, the difference between "5- strongly disagree" and "4-disagree might not be the same as "4-disagree" and "3-average, even though both options are differentiated by one point.

\begin{tabular}{|c|c|c|c|c|c|}
\hline & Relevance & Value & Agreement & Likelihood & Satisfaction \\
\hline 1 & Excellent & High & $\begin{array}{l}\text { Strongly } \\
\text { Agree }\end{array}$ & Definitely & $\begin{array}{l}\text { Very } \\
\text { Dissatisfied }\end{array}$ \\
\hline 2 & Somewhat & Moderate & Agree & $\begin{array}{l}\text { Very } \\
\text { Probably }\end{array}$ & $\begin{array}{l}\text { Moderately } \\
\text { Dissatisfied }\end{array}$ \\
\hline 31 & Poor & Low & Average & Probably & $\begin{array}{l}\text { Slightly } \\
\text { Dissatisfied }\end{array}$ \\
\hline 4 & & None & Disagree & Possibly & $\begin{array}{l}\text { Neutral } \\
\text { Slightly }\end{array}$ \\
\hline 5 & & & $\begin{array}{l}\text { Strongly } \\
\text { Disagree }\end{array}$ & $\begin{array}{l}\text { Probably } \\
\text { Not }\end{array}$ & Satisfied \\
\hline 6 & & & & $\begin{array}{l}\text { Definitely } \\
\text { Not }\end{array}$ & $\begin{array}{l}\text { Moderately } \\
\text { Satisfied }\end{array}$ \\
\hline \begin{tabular}{|l|}
7 \\
\end{tabular} & & & & & Very Satisfied \\
\hline
\end{tabular}

Table 2 Different kind of Likert scale

2.3.2 Indices: An index is a measurement of scores from a group of individual indicators that is used to rank and summarize specific observations to represent a general concept (Hawken \& Munck, 2012). An index is usually used in a survey. For example, Behaviour Problems Index (BPI) is rank or category that provides a measurement of the incidence and severity of children's behaviour problems (Peterson \& Zill, 1986) by collecting and analysing indicators such as measurement of external behaviour (aggressive behaviour) and internal behaviour (withdrawn or sad behaviour). Another example of well-known indices is the Global Gender Gap Index used to measure gender equality (Global, 2017).

Indices are designed to provide useful and beneficial way of collecting data to compose a measurement that could give overview of respondent views on particular belief, attitude, behaviour, and experiences. For example, a researcher is trying to measure entrepreneur job satisfaction, and one of the indicators used is the effectiveness of leadership. This indicator is quite impossible to measure with only one question but can be fulfilled by designing several questions related to effectiveness of leadership and index of related indicators can be created. In order to find entrepreneur satisfaction Index (\%), respondent answers can be calculated by total point score divided by total questions x 100 based on option provided (1-5: strongly agree strongly disagree).

2.3.3 Social Network Analysis (SNA): The formation of the behaviour of an individual can be influenced by the existence and behaviour of individuals involved in their social relationships. Social interaction that occurs can affect how new information or behaviour moves through a particular group. Social network analysis is one of the powerful tools that could be used to examine this relationship. SNA has gained recognition and is increasingly being used by behavioural ecologists and primatologists to describe the patterns and interactions between individuals (Makagon et al., 2012).
Social network analysis (SNA) is a process of quantitative and qualitative analysis to examine human behaviour and maps the pattern of relationship change between actors, individuals, groups, websites, computers, animals, organizations, and/or nations. The SNA consists of nodes (representing individual, actors, computer, animal, or groups) and ties (representing the relationship or association with a line). With advance of technology, the SNA gradually improve both a visual and a mathematical analysis of human relationships (Figure 1). The relationships between actors are the focus of this analytical tool and SNA provide information about direct relationship among actors (manager-assistance manager).

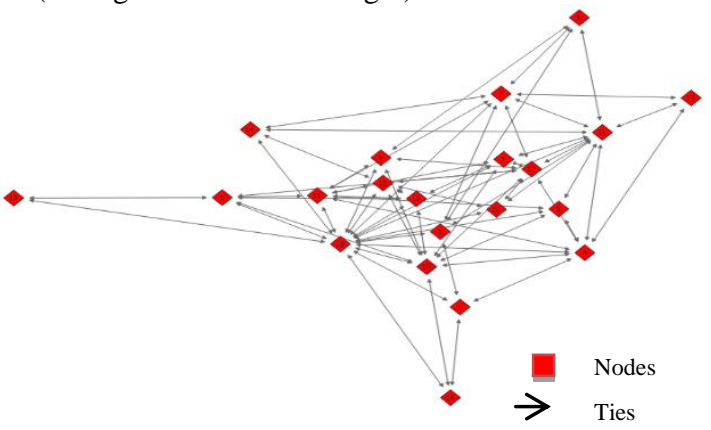

Figure 1 Example of visualizing social networks

SNA can be implemented directly or indirectly. In direct way, researcher will ask question or directly survey the respondent about related topic (Cross et al, 2001). For the indirect way, one of the techniques is to observe selected group to see who they contact, which individuals they approach, their behaviour and who they work with. By using SNA, information can be generated such as which person is trusted the most, who plays a vital role in decision making or who acts as idea generator.

2.3.4 E-scan: Another tool specifically developed to measure the entrepreneurial personality to assist assessment of potential entrepreneurs is E-scan. Driessen and Zwartz (1999) carried out studies to design and build the E-scan for measuring personality traits (Table 3) and nature of the entrepreneur. With this scan, potential entrepreneurs can gain knowledge about their self-personality trait and their capabilities in helping them to survive in their future entrepreneurship (Nandram \& Samson, 2000). This scan can also assist loan organisations (such as banks, government programmes) to evaluate the risk in extending loan to the potential entrepreneur.

\begin{tabular}{|l|}
\hline Need for achievement \\
\hline Need for autonomy \\
\hline Need for Power \\
\hline Social orientation \\
\hline Self-belief \\
\hline Endurance \\
\hline Risk taking \\
\hline Market awareness \\
\hline Creativity \\
\hline Flexibility \\
\hline
\end{tabular}

Table 3 Successful entrepreneur's personality trait in small businesses (E-Scan)

This E-scan is solely for potential entrepreneur who is trying to set up new entrepreneurship. E-scan is a tool based on 114 questions and statements to assess potential entrepreneur (Driessen \& Zwartz, 1999). Netherlands is one of the countries that have widely used this tool, which is available through internet, to measure entrepreneurial competencies. 
2.4 Big Five Factor Model: Lastly, the most established tool in psychology field is Big Five Factor Model. In this model, there are five basic broad cores of personality trait (Figure 2) as believed by many contemporary personality psychologists as result of forty years of research. The five cores described are extraversion, agreeableness, openness, conscientiousness, and neuroticism.

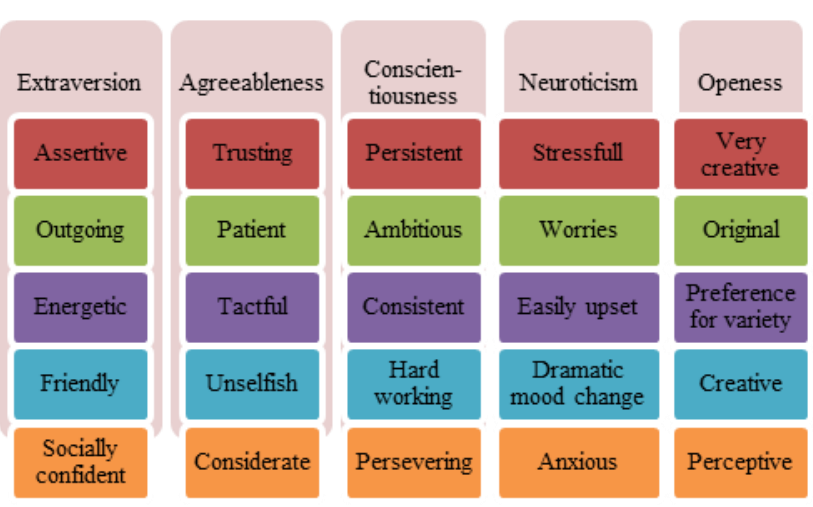

Figure 2 Personality traits in Big Five Model

These five cores stated above do not give a complete explanation of individual personalities but is known as "Big Five" because it covers most of the terms related to personality. These five core traits are not necessarily personality traits but these are related to the characteristics and personality traits that are appropriate.

For example, the core of extraversion contains terms such as sociable, friendly, and outgoing (positive personality traits) and assertive, prefers solitude, and dislikes being the centre of attention (negative personality traits). These personality traits and characteristics and many more form the broader factor of "extraversion".

All of the tools discussed above are from social science perspective, however, whether we realize it or not, entrepreneurship occurs in certain places, certain times, and always involves space. Thus, to depend only on personality and behaviour measurement without consideration of space or spatial aspect seems incomplete. In the section below, the spatial measurement in measuring behaviour is highlighted and discussed.

\section{SPATIAL MEASUREMENT FOR BEHAVIOUR}

\subsection{Spatial Measurement}

Spatial measurement is a measurement involving spatial elements such as distance, area, and volume. In geography perspective, spatial measurement is a measurement that involves numerical values in explaining and describing the characteristic of geographic data, or what some people may call spatial data (Longley et al., 2001). This measurement will measure a simple characteristic of geographic data or spatial data such as area, length, height, width, and the relationship among related objects such as distance, direction, and pattern. To measure entrepreneur behaviour, not only simple measurement is needed, but more sophisticated methods are needed to reveal hidden information.

In spatial measurement scale, one topic that will be included in measurement of geographic data and spatial data is whether features are natural or man-made. Spatial data and non-spatial data (attribute data) require standardized scale measurement. In contrast, while location and position can be easily measured with numeric, some non-spatial data is not easily measured with absolute measurement. The scales from descriptive statistics, which are nominal, ordinal, interval, and ratio, are used to measure this attribute data (Table 4).

\begin{tabular}{|l|c|c|}
\hline Scale level & Natural Features & Man-Made Features \\
\hline Nominal & $\begin{array}{c}\text { Entrepreneurship type } \\
\text { (Food catering, accessory, } \\
\text { workshop) }\end{array}$ & $\begin{array}{c}\text { Electronic Brand } \\
\text { (Beko, Electrolux, } \\
\text { Sharp) }\end{array}$ \\
\hline Ordinal & $\begin{array}{c}\text { Month Order } \\
\text { (January < February } \\
<\text { March) }\end{array}$ & $\begin{array}{c}\text { Type of entrepreneur } \\
\text { (Micro < } \\
\text { Small<Medium) }\end{array}$ \\
\hline Interval & $\begin{array}{c}\text { Duration Of Operation } \\
\text { Hour } \\
(6-8,9-11,12-14)\end{array}$ & $\begin{array}{c}\text { Percentage of profit } \\
(1-20,21-40,41-60)\end{array}$ \\
\hline Ratio & $\begin{array}{c}\text { Distance } \\
\text { (Distance of agent A is two } \\
\text { time far from agent B). }\end{array}$ & $\begin{array}{c}\text { Income } \\
\text { time when he became } \\
\text { entrepreneur) }\end{array}$ \\
\hline \multicolumn{2}{|c|}{ Table 4 Scales from descriptive statistics }
\end{tabular}

In nominal level, data are for categories of unranked qualitative data. Nominal level can be categorized by their type, but not ranked from low to high. For example, entrepreneurs are categorized based on their type of entrepreneurship (food catering, accessory, workshop) and this is no implication for the distinction (without a quantitative meaning). Ordinal level is quite different from nominal level as they are ranked or ordered from high to low. Type of entrepreneur is ranked by order from Micro to Medium are one of the examples for ordinal level. Nominal and ordinal levels are qualitative data, while interval and ratio are quantitative data. Interval level is usually used for temperature and year where the zero point is arbitrary on the measurement scale. For example, the duration of shop operation hours by entrepreneur show the interval level of data measurement. Lastly ratio level could be used for data that have absolute zero. For example, zero distance means there is no distance at all, whether in millimetre or kilometre, unlike zero degrees Celsius.

Spatial measurement can provide a tool to measure behaviors in objective way, even though behaviours are something quite difficult to measure. This is because behaviour usually involves spatial aspect that can be measured objectively. These measurements are provided in spatial analysis in Geographical Information System (GIS) software. Usually, spatial measurement can automatically measure in GIS. GIS software is usually referred to as computer system tool that is specifically used to store, manage, analyse, manipulate, and visualize geospatial data. With the help of GIS, entrepreneur behaviour can be measured, analysed, and visualized to produce more meaningful information about entrepreneur by using spatial analysis.

\subsection{Spatial Analysis}

To measure entrepreneur behaviour, spatial analysis in GIS can be used to generate information, answer questions and support decision making. Spatial analysis is the backbone of GIS because with spatial analysis, spatial data related to entrepreneur can be transformed and manipulated. Measurements and other methods can be applied to produce useful and meaningful information. Entrepreneur behaviour can be measured by using spatial analysis because spatial analysis 
provides various methods from simple to sophisticated method. Commonly, spatial analysis consists of six categories such as queries and reasoning, transformations and manipulation, measurements, descriptive statistics, optimization, and hypothesis testing (Longley et al., 2001).

To measure entrepreneur behaviour, several methods are recommended, while the rest of the methods can be used to produce, support, and further analyse entrepreneur behaviour for related information. From the six methods provided, simple query can be used to answer questions such as "what kind of entrepreneurship existed here", "where are your agents located and how many are there", "how many of your suppliers are in this area", "how long have you stayed in this location" in order to gain basic information about entrepreneur. Simple measurement methods play a role to measure basic characteristics of spatial data (for example: a shop) such as size, length, height, width, operation hours of the shop and the relationship among related objects such as distance between entrepreneur shop from supplier, direction of shop, and pattern of entrepreneurship shop in related area. All of these questions and measurements are based on spatial element such as location, distance, area, height and others.

A more complicated method is optimization method, which concerns ideal selection of location for related problem (maximizing and minimizing) such as shortest route selection, location allocation model, site selection for new branch and others which are beneficial to supply related information in measuring entrepreneur behaviour. For example, site selections application suggest a very crowded and entrepreneur willing to set up a new branch in competitive area where the distribution of competitor is quite high. This situation can show the confidence level of entrepreneur as the entrepreneur is not afraid to face competitive challenge in new area. Descriptive statistic and hypothesis testing can be used for further analysis. In order to measure entrepreneur behaviour by spatial measurement, there is a need for geographic features or spatial data that involve entrepreneurial action and behaviour for storage in GIS software. With this set of data, and suitable method, abundant information related to entrepreneur behaviour can be produced. Without related spatial data, any process, measurement and analysis cannot be carried out despite powerful software and hardware.

\subsection{Spatial Data}

Spatial data, also known as geospatial data (geo data, geo-data), is often defined as geographical data, but geographic data actually is only a part of spatial data. Generally, spatial data brings information that answers questions about location, shape, size, and component or spatial element and also the relationship between objects. Aerial photos, satellite images, heat images, Digital Elevation Model (DEM) and maps are some examples of spatial data. Spatial data has long been recognized as having an important influence on the entrepreneurship field, which typically requires travel planning information (or the nearest route), the distance of the customer or the location of the premises or new branch. However, the explorations of spatial data to measure entrepreneur behaviour are few in number (Kwan, 2000; Carvalho, 2017). To explore spatial measurement for entrepreneur behaviour, spatial element as basic block of spatial data needs to be clarified. This is due to the related knowledge of spatial element only; we can view entrepreneur behaviour in spatial perspective. In spatial perspective, several spatial elements can be used to identify and measure entrepreneur behaviour such as location, distance, length, width, height, pattern, and area. These simple spatial elements can be used to measure entrepreneur behaviour as discussed below.

\subsection{How to Measure Behaviour Using Spatial Measurement}

Some people might question how behaviour should be measured. For example, the persistence of entrepreneur differs depending on individual. Persistence is subjective and related to emotion and feeling which are quite difficult to measure, so how can we quantify this personality trait and behaviour of persistence entrepreneur? In order to measure the behaviour of persistence entrepreneur in terms of spatial measurement, we need to look in spatial perspective that might not be obvious or sometimes overlooked. When said entrepreneur is persistent, usually it shows in the entrepreneur's action and activity. Some entrepreneurs are said to be persistent as they continue to pursue previously selected entrepreneurial at one location even though they have faced a numbers of failures, impediments, or threats for a long time (Holland \& Shepherd, 2013). In this statement, there two spatial elements involved, location and time. So here we can quantify this data in terms of time by using spatial measurement scale. As the time increased, entrepreneur is said to be more persistent. So here we already use spatial measurement to measure persistence behaviour in objective ways and simple ways in terms of time (spatial element).

Another example of entrepreneur behaviour that can be spatially measured is opportunity oriented behaviour. An entrepreneur who is said to be opportunity oriented will explore and try to utilize idle resources surrounding him. As the number of different location of resources increases, entrepreneur is said to be more opportunistic as he/she can see the opportunities that might be unconsciously ignored by others. In this situation, pattern is identified and used to measure opportunistic behaviour. Other behaviours required by an entrepreneur can be measured as long as there are spatial data and spatial element involved and can be identified in entrepreneur actions.

\subsection{Exploration of Spatial Measurement for Human Behaviours}

Researches on the nature of spatial components in entrepreneurship have received warm welcome from scientists and policy-makers as place and location play very critical roles in entrepreneurship (Qingfang, 2013). Specifically, the use of GIS to assist in predicting and making decisions on common geographical issues in entrepreneurship has become widespread since the introduction of GIS. Previous studies have also proven that the personality and behaviour of entrepreneurs are influenced by space and ability to change space (Heidegger, 1962; Harari et al., 2016; Harari et al., 2017). The study of human spatial behaviour encompasses various aspects such as travel and way finding, migration, decision-making and selective behaviour, as well as space cognition, and environmental perception (Golledge \& Stimson, 1997). In past, methods for human behaviour were limited by restricted individual data and analytical tools available (Kwan, 2000).

These spatial measurements for behaviour seem impossible at first, but with the advanced technology nowadays, spatial measurement for entrepreneur behaviours is possible. The evolution of technology has enabled researcher to collect data in individual level where in the past this data was quite unreachable in certain areas (as example, a micro entrepreneur in remote area). Improvements of technology like geospatial technology have made the collection of real-time automated 
data possible through GPS. The availability of GPS usage in smartphones can help researcher to obtain individual data easily, especially location data and spatial data that are critical components in spatial measurement. However, based on literature review, there very limited researches have been conducted (Williams et al., 2015), and application of spatial measurement for entrepreneur behaviour, although another area of human behaviour (shopper, tourist) has been well received by other scientists (Van Acker et al., 2010).

For example, a few studies have shown the possibility to relate and measure personality trait based on behaviour (De Montjoye, 2013; Van Acker et al., 2010;) as humans are normally characterised by the occurrence of repeated activity in certain space such as commute from residential house to the workplace (Perchoux et al., 2016). However, this geo-spatial movement varies in shape (Pappalardo et al., 2015) and size (Gonzalez et al., 2008). Alessandretti et al. (2018) adopt explorationexploitation point of view to analyse the relationship between personality behaviour and spatial strategies using the information obtained from their smart phone. They measure personality in space based on frequency (the number of repeated times going to certain place), the exploration of new opportunities (visiting new place for searching new resource) and the period of time an individual spends at the certain place.

Then, the information obtained is associated with the Big Five personalities which show one of the personalities, such as extraverted individuals are more explorative (initiator) and more likely to be risk-takers. Another study also utilized mobile phone based measurement (e.g., message and call record, contact and spatial behaviour) to show the daily routine distance to predict neuroticism but the direction of the relationship was not reviewed (De Montjoye, 2013). Monsted et al. (2018) suggest twenty-two mobile phone measurements (such as distance travelled) relying on GPS-based location data which show the possibility of relationship of personality and behaviour in spatial perspective; however no further explanation as to how they related to each other was reported. One of the latest studies by Ai et al., (2019), which aims to systematically examine relation between the Big Five personality traits, collected data by conventional self-report method and spatial behaviour using smartphone method which produce result that show the relationship between the extraverted personality with the number of various places visited, the entropy of movement on weekends and the overall distance traveled.

Even though there are strong relationships between personality trait and spatial behaviour, the effort to measure personality trait in geography or GIS research is still sporadic. This is because human and entrepreneur behaviour and personality is something subjective, qualitative and "unmeasurable", so spatial measuring human behaviour and personality in terms of objective and quantitative ways is quite difficult without proper approach. Also, entrepreneur behaviours and personality trait are usually very closely related to the field of social psychology, which examines the personal and situational factors affecting individual social behaviour. Usually this study of behaviour is measured independently from spatial position, if there is only a small part. However, in reality, human behaviour affects space and space affects human behaviour and personality. Another reason is because the events that involve geographical features seem more relevant, not questionable and the use of spatial approach can be easily decided such as flood problem or deforestation (geographical problems).
However, events that do not clearly involve geographic objects such as personality and entrepreneur behaviour might raise questions as to how spatial approach can be used. This situation occurs because of the difficulty in identifying geographical data involved in this event and this event might only be viewed as a social event. Therefore, this might lead to failure of recognition of the intangible spatial data which link this event to the space. In general, people might view the action or behaviour of human to be solely based on their selfpersonality and situational, however if this event is observed in depth, there are geographical features involved indirectly. For example, for perseverance, entrepreneur will strive in terms of percentage of houses in conducting entrepreneurial activities, even if they did not have spacious space. In this situation, the geographical feature involved is their house serves as a shop.

\section{CONCLUSION}

This paper presents another way to measure "immeasurable" human behaviour in contrast to conventional ways in terms of non-spatial. By quantifying the human behaviour and correlating with the spatial element, human behaviour which is often regarded as qualitative event can now be measured objectively with the availability of technology, tool, and method. Measuring human behaviour should not only rely on using one single tool (non-spatial measurement), but identifying and implementing a combination of tools effectively can produce and support the meaningful information and complement each part of information (social focus more on psychological factor while spatial focus on space). With this information, related agencies can assess entrepreneur behaviour and have better judgement for better decision making in providing loan to most potential entrepreneurs.

\section{ACKNOWLEDGEMENTS}

This research was partially funded by UTM Research University Grant, Vot Q.J130000.3552.05G34 and Vot Q.J130000.3552.06G41.

\section{REFERENCES}

Ai, P., Liu, Y., \& Zhao, X. 2019. Big Five personality traits predict daily spatial behavior: Evidence from smartphone data. Personality and Individual Differences, 147, 285-291. doi:10.1016/j.paid.2019.04.027

Aitken, S. C. 1991 Person-environment theories in contemporary perceptual and behavioural geography I: personality, attitudinal and spatial choice theories. Prog Hum Geogr 15(2):179-193

Alessandretti, L., Lehmann, S, \& Baronchelli, A. 2018. "Understanding the interplay between social and spatial behaviour," EPJ Data Sci. 7, 36

APA, 2017. Personality. American Psychological Association. Retrieved http://www.apa.org/topics/personality

Asamani, L, \& Mensa, A. O., 2013. Entrepreneurial Inclination Among Ghanaian University Students: The case of University of Cape Coast, Ghana. International Journal of 
The International Archives of the Photogrammetry, Remote Sensing and Spatial Information Sciences, Volume XLII-4/W16, 2019 6th International Conference on Geomatics and Geospatial Technology (GGT 2019), 1-3 October 2019, Kuala Lumpur, Malaysia

Social, Behavioural, Educational, Economic, Business and Industrial Engineering. 5 (19):113-125.

Baumol, W .J. 1996. Entrepreneurship: Productive, unproductive, and destructive. Journal of Business Venturing, $11,3-22$.

Branstätter, H., 2011. Personality Aspects of Entrepreneurship: A Look at Five Meta-Analyses, Personality and Individual Differences, 51(3), 222-230.

Buang, N. A., 2002. Asas Keusahawanan. Shah Alam: Fajar Bakti. Polyghraphic (M) Sdn.Bhd.

Carvalho, L. C., 2017. Handbook of Research on Entrepreneurial Development and Innovation Within smart cities. United State of America. IGI Global

Chell E, Haworth J, \& Brearly C., 1991. The entrepreneurial personality: Concepts, cases and categories. London: Routledge

Chell, E., 2008. The Entrepreneurial personality. A social construction (2nd ed.). London: Routledge.

Cross, R., Parker, A., Prusak, L., \& Borgatti, S. P., 2001. Knowing what we know: Supporting knowledge creation and sharing in social networks. Organizational Dynamics 30(2), $100-120$.

De Montjoye YA., Quoidbach J., Robic F., Pentland A. 2013. Predicting Personality Using Novel Mobile Phone-Based Metrics. In: Greenberg A.M., Kennedy W.G., Bos N.D. (eds) Social Computing, Behavioral-Cultural Modeling and Prediction. SBP 2013. Lecture Notes in Computer Science, vol 7812. Springer, Berlin, Heidelberg

Doran, J., McCarthy, N., O’Connor, M. \& Nsiah, C., 2018. "The role of entrepreneurship in stimulating economic growth in developed and developing countries", Cogent Economics \& Finance, 6 (1), 1-14

Driessen, M. P., \& Zwart, P. S., 1999. "The Entrepreneur Scan Measuring Characteristics and Personality traits of Entrepreneurs", working paper, University of Groningen

Frese, M. \& Gielnik, M. M., 2014. The psychology of entrepreneurship. Annual Review of Organizational Psychology and Organizational Behaviour, 1 (1).

Global Gender Gap Report, 2017. Global Gender Gap Report 2017. (2019-05-11).

Golledge, R. G. \& Stimson, R. J., 1997. Spatial behaviour: A geographic perspective The Guilford Press, New York

Gonzalez, M. C., Hidalgo, C. A., \& Barabasi, A-L., 2008 Understanding individual human mobility patterns. Nature 453(7196):779-782

Guerrero, M., Rialp, J., \& Urbano, D., 2008. The impact of desirability and feasibility on entrepreneurial intentions: A structural equation model. International Entrepreneurship and Management https://doi.org/10.1007/s11365-006-0032-x

Hachana, R., Berraies, S. \& Ftiti, F., 2018. Identifying personality traits associated with entrepreneurial success: does gender matter? Journal of Innovation Economics and Management, 27 (3), 169-193.

Harari, G. M., Lane, N. D., Wang, R., Crosier, B. S., Campbell, A. T., \& Gosling, S. D. 2016. Using smartphones to collect behavioral data in psychological science: Opportunities, practical considerations, and challenges. Perspectives on Psychological Science, 11(6), 838-854

Harari, G. M., Muller, S. R., Aung, M. S., \& Rentfrow, P. J. 2017. Smartphone sensing methods for studying behavior in everyday life. Current Opinion in Behavioral Sciences, 18, 83-90.

Hawken, A., \& Munck, G. L., 2012. Cross-national indices with gender-differentiated data: What do they measure? How valid are they? Social Indicators Research (published online: 24 April 2012).

\section{Heidegger M. 1962. Being and Time. Oxford: Blackwell}

Holland, D. and Shepherd, D.A., 2013. "Deciding to persist: adversity, values, and entrepreneurs' decision policies", Entrepreneurship Theory and Practice, Vol. 37 No. 2, pp. 331-358.

Jamieson, S., 2004. Likert scales: How to (ab)use them. Medical Education, 38, 1212 -1218.

Joshi, A., Kale, S., Chandel, S., \& Pal, D. K., 2015. Likert Scale: Explored and Explained. British Journal of Applied Science \& Technology, 7(4), 396-403.

Kerr, S. P., Kerr, W. R, \& Tina Xu. 2017. Personality traits of entrepreneurs: A review of recent literature." Working Paper.

Khalique, M., Md Isa, A. H., Shaari, J. A. N., Ageel, A., 2011. Challenges Faced by the Small and Medium Enterprises (SMEs) in Malaysia: An Intellectual Capital Perspective (March 14, 2011). International Journal of Current Research, Vol. 3, No. 6, p. 398, June 2011.

Khan, M. A., 2014. Issues of Entrepreneurship and Innovation Business Management. International Journal of Research, 2 (2), 71-76.

Kirby, D., 1992. Developing graduate entrepreneurs: The U.K. graduate enterprise programme. Entrepreneurship, innovation and change, 1(2).

Kirchhoff, B. A., 1991. Entrepreneurship's contribution to economics. . Theory Practice 16(2):93-112

Kirkley, W. W., 2016. "Entrepreneurial behaviour: the role of values", International Journal of Entrepreneurial Behaviour \& Research, 22 (3), 290-328

Korent, D., Vukovic, K., Brcic, R., 2015. Entrepreneurial Activity and Regional Development. Economic Research 
The International Archives of the Photogrammetry, Remote Sensing and Spatial Information Sciences, Volume XLII-4/W16, 2019 6th International Conference on Geomatics and Geospatial Technology (GGT 2019), 1-3 October 2019, Kuala Lumpur, Malaysia

\section{Ekonomska Istrazivanja, 28(1), 939-958}

Kwan, M.-P., 2000. Analysis of human spatial behaviour in a GIS environment: recent developments and future prospect Journal of Geographical Systems, 2 (1), pp. 85-90

Longley, P. A., Goodchild, M. F., Maguire D. J. \& Rhind, D. W., 2001. Geographic Information Systems and Science. John Wiley \& Sons Ltd. Reproduced

Mahmood R., 2009. Prestasi Perusahaan Kecil: Satu kajian perbandingan ke atas program mikrokredit Amanah Ikhtiar Malaysia (AIM) dan Tabung Ekonomi Kumpulan Usaha Niaga (TEKUN). Tesis Ph.D. Universiti Malaya.

Makagon, M. M., McCowan, B., \& Mench, J. A., 2012. How can social network analysis contribute to social behaviour research in applied ethology? Applied Animal Behaviour Science 138:152-161.

Markman, G. \& Baron, R., 2003. Person-Entrepreneurship Fit: Why Some People Are More Successful as Entrepreneurs than Others. Human Resource Management. Review. 13, 281-301.

Monsted, B., Mollgaard, A., \& Mathiesen, J. 2018. Phonebased metric as a predictor for basic personality traits. Journal of Research in Personality, 74, 16-22.

Nandram, S. S. \& Samson, K. J., 2000. Successful entrepreneurship: more a matter of character than of knowledge (in Dutch with English summary). Nyenrode Center for Entrepreneurship, Breukelen, The Netherlands, 242

Naude, W., 2010. Promoting entrepreneurship in developing countries: policy challenges. World Institute for Development Economics Research of the United Nations University (UNUWIDER) Policy Brief, 42010, 1-8.

Pappalardo L, Simini F, Rinzivillo S, Pedreschi D, Giannotti F, Barabási A-L. 2015. Returners and explorers dichotomy in human mobility. Nat Commun 6:8166

Perchoux, C., Chaix, B., Cummins, S., \& Kestens, Y. 2013. Conceptualization and measurement of environmental exposure in epidemiology: accounting for activity space related to daily mobility. Health \& Place, 21, 86-93. doi:10.1016/j.healthplace.2013.01.005

Peterson, J. L., \& Zill, N., 1986. Marital disruption, parentchild relationships, and behavioural problems in children. Journal of Marriage and the Family, 48(2), 295. http://www.isr.umich.edu/src/child-development/home.html

Podsakoff, P. M., MacKenzie, S. B., Lee, J, Podsakoff, N. P., 2003. Common method biases in behavioural research: A critical review of the literature and recommended remedies. Journal of Applied Psychology, 88, 879- 903.

Qingfang W., 2013. "Constructing a multilevel spatial approach in ethnic entrepreneurship studies", International Journal of Entrepreneurial Behaviour \& Research, Vol. 19 Issue: 1, pp. 97-113.
Shane, S., \& Venkataraman, S. 2000. The Promise of Entrepreneurship as a Field of Research. Academy of Management Review, 25(1), 217-226.

SME Corp, 2010. SME Annual Report 2009/10. Kuala Lumpur, National SME Development Council.

Sorenson, O., 2005. Social networks and industrial geography. In U. Cantner, E. Dinopoulos, \& R. F. Lanzillotti, Entrepreneurship, the New Economy and Public Policy (p. 55). Germany: Springer Verlag Berlin Heidelberg.

Van Acker, V., Van Wee, B. \& Witlox, F. 2010. When transport geography meets social psychology: toward a conceptual model of travel behaviour. Transp Rev 30(2):219 240

Wong, K. P., Ho, Y. P., \& Autio, E., 2005. Entrepreneurship, Innovation and Economic Growth: Evidence from GEM data. Small Business Economics, 24, 335-350.

Williams, N. E., Thomas, T. A., Dunbar, M., Eagle, N., \& Dobra, A. 2015. Measures of daily spatial behaviour using mobile phone records enhanced with GIS data. PLoS One, 10(7), e0133630.

Yusof, A. A., 2003. Prinsip keusahawanan. Pearson Malaysia, Petaling Jaya, Selangor

Zaidatol, A. L. P., 2007. Usahawan dan keusahawanan satu perspektif pendidikan. Serdang: Universiti Putra Malaysia.

Revised August 2019 